\title{
Towards novel angiogenesis inhibitors based on the conjugation of organometallic platinum(II) complexes to RGD peptides
}

\author{
Ana Zamora,${ }^{[a, b]}$ Albert Gandioso, ${ }^{[a]}$ Anna Massaguer,${ }^{[\mathrm{c}]}$ Silvia Buenestado, ${ }^{[\mathrm{d}]}$ Carme Calvis, ${ }^{[\mathrm{d}]}$ Jose Luis \\ Hernández, ${ }^{[d]}$ Francesc Mitjans, ${ }^{[d]}$ Venancio Rodríguez,${ }^{[b]}$ José Ruiz, ${ }^{*[b]}$ and Vicente Marchán ${ }^{*[a]}$ \\ [a] Dr. A. Zamora, A. Gandioso, Dr. V. Marchán \\ Departament de Química Inorgànica i Orgànica, Secció de Química Orgànica \\ University of Barcelona \\ Martí i Franquès 1-11, E-08028 Barcelona (Spain) \\ E-mail: vmarchan@ub.edu \\ [b] Dr. A. Zamora, Dr. V. Rodríguez, Prof. J. Ruiz \\ Departamento de Química Inorgánica \\ Universidad de Murcia and Institute for Bio-Health Research of Murcia (IMIB-Arrixaca) \\ E-30071 Murcia (Spain) \\ E-mail: jruiz@um.es \\ [c] Dr. A. Massaguer \\ Departament de Biologia \\ Universitat de Girona \\ E-17071 Girona (Spain) \\ [d] Dr. S. Buenestado, Dr. C. Calvis, Dr. J. L. Hernández, Dr. F. Mitjans \\ Biomed Division, LEITAT Technological Center \\ E-08028 Barcelona (Spain) \\ Supporting information for this article is given via a link at the end of the document.((Please delete this text if not appropriate))
}

\begin{abstract}
A novel conjugate between a cyclometalated platinum(II) complex with dual anti-angiogenic and antitumor activity and a cyclic peptide containing the RGD sequence (-Arg-Gly-Asp-) has been synthesized by combining solid- and solution-phase methodologies. Although peptide conjugation rendered a non-cytotoxic compound in all tested tumor cell lines $\left(+/-\alpha_{v} \beta_{3}\right.$ and $\alpha_{v} \beta_{5}$ integrin receptors), the anti-angiogenic activity of the Pt-c(RGDfK) conjugate in HUVEC cells at sub-cytotoxic concentrations opens the way to the design of a novel class of angiogenesis inhibitors through conjugation of metallodrugs with high anti-angiogenic activity to cyclic RGDcontaining peptides or peptidomimetic analogues.
\end{abstract}

\section{Introduction}

Angiogenesis, the process by which new blood vessels are formed from pre-existing vessels, plays a crucial role in several events such as embryogenesis, growth and wound healing. ${ }^{[1,2]}$ Likewise it is widely accepted that aberrant angiogenesis occurs in other pathological conditions, including cancer growth and metastasis due to the necessity of supplying nutrients and oxygen into malignant tumor tissues. Owing to the potential of angiogenesis as a therapeutic target for blocking cancer growth, many efforts have been devoted in the last decades to the development of novel antiangiogenic agents. ${ }^{[3]}$ FDA-approved angiogenesis inhibitors based on antibodies (bevacizumab) or small molecules (sorafenib and sunitinib) are currently being used in the clinics for the treatment of various cancers, either alone or in combination with other chemotherapeutic agents. ${ }^{[4]}$ However, they are not exempt from drawbacks, including severe toxic side effects. ${ }^{[5]}$
Bioactive peptides have also demonstrated great potential in antiangiogenic therapies, as exemplified by Cilengitide (1, Scheme 1). This cyclic RGD pentapeptide developed by Kessler and collaborators in the early $90 \mathrm{~s}$ is currently in late-stage clinical trials for the treatment of glioblastoma, as well as in preclinical studies in combination with classical therapies such as radio and cytotoxic agents due to its lack of toxicity and high drug tolerance $e^{[6-8]}$ (e.g., Cilengitide with cetuximab, cisplatin and 5 -fluorouracil in metastatic squamous cell cancer of the head and neck; ${ }^{9}$ Cilengitide with cetuximab and platinum-based chemotherapy as first-line treatment in advanced non-small-cell lung cancer). ${ }^{10}$ Peptide-based drugs such as Cilengitide offer several advantages over small-based drugs or large antibodies since key factors such as enzymatic stability, target specificity and toxicity can be fine-tuned through chemical modifications (e.g., cyclization, $\mathrm{N}$-methylation and incorporation of a $D$-amino acid residues) to obtain privileged bioactive structures. ${ }^{[11-12]}$ In fact, Cilengitide is the result of constraining the RGD motif in its optimum conformation for binding to the $\alpha \beta_{3}$ integrin receptor (and to a lesser extent to $\alpha_{v} \beta_{5}$ and $\alpha_{5} \beta_{1}$ ). ${ }^{[6-8]}$ Integrins are a class of heterodimeric transmembrane receptors that mediate cell-cell communication and cell-extracellular matrix interactions, and many of them, including $\alpha_{v} \beta_{3}$ and $\alpha_{v} \beta_{5}$, are involved in tumor angiogenesis. ${ }^{[13]}$ For this reason, a large number of RGDcontaining peptides (including Cilengitide and other analogues) or peptidomimetics have been developed to target integrin receptors with the aim of searching for novel anticancer agents. In addition, the particular over-expression of $\alpha_{v} \beta_{3}, \alpha_{v} \beta_{5}$ and $\alpha_{5} \beta_{1}$ integrins in tumor cells offers the possibility of using RGD peptides as delivery vectors in both therapy and diagnosis. ${ }^{[14-16]}$

On the other hand, the development of non-conventional metal complexes with antiangiogenic properties offers great 
potential in chemotherapy as an alternative to classical platinum drugs based on cisplatin and derivatives. In spite of the relatively large number of non-toxic angiogenesis inhibitors based on $\mathrm{Ru}(\mathrm{II}), \mathrm{Rh}(\mathrm{II})$ and $\operatorname{Ir}(\mathrm{III})$ complexes reported in recent years, ${ }^{[17-19]}$ bioactive metallodrugs with dual cytotoxicity and antiangiogenic properties are scarce ${ }^{[20-23]}$ particularly in the platinum field. Recently, we have described a family of cyclometalated $\mathrm{Pt}(\mathrm{II})$ complexes of the type [Pt(dmba-R)(DMSO)Cl] $(\mathrm{dmba}=\mathrm{C}, \mathrm{N}$ dimethylbenzylamine; $\mathrm{R}$ being $\mathrm{MeO}, \mathrm{Me}, \mathrm{H}, \mathrm{Br}, \mathrm{F}, \mathrm{CF}_{3}$, and $\mathrm{NO}_{2}$ substituents at positions 4 and 5 of the phenyl ring; see Scheme 1) exhibiting $I C_{50}$ values in the submicromolar range in the A2780 cell line and inhibition of angiogenesis at a close concentration to their $\mathrm{IC}_{50}$ values. ${ }^{[24]}$ Since introduction of substituents into the $\mathrm{C}, \mathrm{N}$-chelating ligand did not influence their dual antiangiogenic and cytotoxic activities in vitro, the attachment to a carrier agent was envisaged as a promising strategy to improve the pharmacological properties of such novel metallodrugs.<smiles>[R]NC(=O)[C@H](CC(=O)O)NC(=O)CNC(=O)[C@H](Cc1ccccc1)NC(=O)C(N[R])C([R])[R]</smiles>

$\mathrm{R}=\mathrm{CH}_{3}, \mathrm{R}^{\prime}=-\mathrm{CH}\left(\mathrm{CH}_{3}\right)_{2} \quad \mathrm{c}(\mathrm{RGDFNMeV})(\mathbf{1})$ $\mathrm{R}=\mathrm{H}, \quad \mathrm{R}^{\prime}=-\left(\mathrm{CH}_{2}\right)_{4} \mathrm{NH}_{2} \quad \mathrm{c}(\mathrm{RGDfK})$

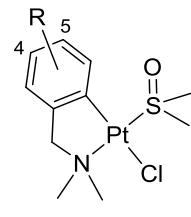

$\mathrm{R}=\mathrm{H} \quad \mathrm{Pt}(\mathbf{2})$

$\mathrm{R}=\mathrm{MeO}, \mathrm{Me}, \mathrm{Br}, \mathrm{F}, \mathrm{CF}_{3}, \mathrm{NO}_{2}$<smiles>O=C(COCCOCCNC(=O)c1ccccc1)NC1CC2CCC1C2</smiles>

RGD peptide

Organoplatinum(II) complex

dual antitumor and antiangiogenic activity

$\alpha_{v} \beta_{3}$ integrin targeting antiangiogenic activity

Scheme 1. General structure of the integrin antagonist RGD peptides, Cilengitide (1) and $\mathrm{c}(\mathrm{RGDfK})$, the dual antitumor and antiangiogenic $\mathrm{Pt}$ (II) complexes, and schematic representation of the Pt-c(RGDfK) conjugate (3).

Herein, we will focus on the conjugation of a promising organoplatinum(II) complex with dual antitumor and antiangiogenic activity, $[\mathrm{Pt}(\mathrm{dmba})(\mathrm{DMSO}) \mathrm{Cl}](2$, Scheme 1$),{ }^{[24]}$ to $c($ RGDfK), a cyclic conjugatable version of the RGD motif, with the aim of exploring the anti-angiogenic activity of the resulting conjugate. Solid-phase peptide synthesis (SPPS) in combination with solution-phase approaches have been used for the preparation of the bioconjugate ( 3 , Scheme 1$)$, and the effect of peptide conjugation on the biological activity of the parent $\mathrm{Pt}(\mathrm{II})$ complex has been investigated in a panel of human cancer cell lines that over-express or not integrin receptors related to angiogenesis.

\section{Results and Discussion}

\section{Synthesis and characterization of the Pt-c(RGDfK) conjugate (3)}

The preparation of the Pt-c(RGDfK) conjugate (3) relied on the synthesis of the peptide and the subsequent conjugation to the metal complex in solution (Scheme 2). This approach is especially useful for the preparation of bioconjugates incorporating sensitive metallodrugs based on $\mathrm{Pt}(\mathrm{II})$ and $\mathrm{Pt}(\mathrm{IV})$ complexes. ${ }^{[25-29]}$ The conjugation of the platinum complex 2 with the peptide via an amide bond, required the incorporation of a carboxylic function in the $\mathrm{C}, \mathrm{N}$-chelating ligand. Therefore, 4(dimethylamino)methyl)benzoic acid was prepared through the reaction of 4-(chloromethyl)benzoic acid with dimethylamine, and subsequently cyclometalation of cis- $\left[\mathrm{PtCl}_{2}(\mathrm{DMSO})_{2}\right]$ afforded complex 4 in $55 \%$ yield (Scheme $2 \mathrm{~A}$ ), which was characterized by NMR spectroscopy (Figures S1-S3). The ${ }^{1} \mathrm{H}$ NMR spectrum shows all the diagnostic resonances including the $\mathrm{CH}^{6}$ of $\mathrm{dmb}$ ba ligand flanked by ${ }^{195} \mathrm{Pt}$ satellites and a broad signal at high-field corresponding to the carboxylic acid function required for conjugation. Complex 4 was also characterized by positive-ion high-resolution ESI MS.

On the other hand, it is worth noting that the wellestablished angiogenesis inhibitor Cilengitide cannot be conjugated to a cargo drug as it is, since three amino acids are essential for binding to the integrin receptors (RGD triad), D-Phe is involved in hydrophobic interactions and the $\mathrm{N}$-methylated $\mathrm{Val}$ residue has no derivatizable functional group. Although the incorporation of $\mathrm{N}$-methyl amino acids turned out to be one of the most important structural modifications of Cilengitide, ${ }^{[30]}$ replacement of $\mathrm{MMeVal}$ by Lys or Glu provides new functional groups that can be further functionalized while retaining the integrin binding affinity. ${ }^{[31]}$ Thus, a conjugatable version of Cilengitide, $\mathrm{c}(\mathrm{RGDfK})$, has been employed and further modified through the $\varepsilon$-amino function of the lysine residue. As shown in Scheme 2B, peptide 5 incorporating a polyethyleneglycol spacer at the side chain of the lysine residue of $c(R G D f K)$ was first synthesized by combining SPPS for the assembly of the peptide sequence and solution-phase reactions for the cyclization and removal of the side chain protecting groups. Briefly, the linear cyclopentapeptide was assembled on 2-chlorotrityl chloride resin using standard Fmoc/tBu chemistry, cleaved under mild acidic conditions (1\% AcOH for $30 \mathrm{~min}$ ) and cyclized with PyBOP in the presence of DIPEA to afford the protected peptide $\mathrm{c}[-$ $\operatorname{Arg}(\mathrm{Pbf})$-Gly-Asp(tBu)-D-Phe-Lys(linker)-]. Finally, the remaining side chain protecting groups were eliminated by acidic treatment, and the desired peptide $\mathbf{5}$ was purified by reversed-phase HPLC and characterized by ESI MS. 
$\underset{\mathrm{Cl}}{\frac{\mathrm{dry} \mathrm{THF}}{45 \%}}$

$\longrightarrow$ Fmoc/tBu SPPS
1) $\mathrm{H}_{2} \mathrm{~N}$-Asp(tBu)-D-Phe-Lys(Boc-linker)-ATFE/DCM
$1: 1: 8,30 \mathrm{~min}$
2) PyBOP, DIPEA
DMF, $18 \mathrm{~h}$

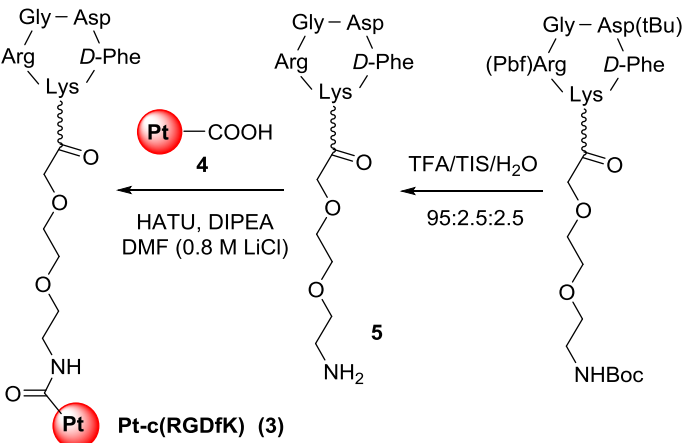

Scheme 2. (A) Synthesis of the platinum complex 4 and (B) schematic representation of the solid-phase approach used for the synthesis of the Ptc(RGDfK) conjugate (3).

The Pt-c(RGDfK) conjugate (3) was synthesized by reaction of peptide 5 with complex 4 (Scheme 2), which was previously activated with HATU and DIPEA in anhydrous DMF $(0.8 \mathrm{M} \mathrm{LiCl})$ for $10 \mathrm{~min}$. These conjugation conditions were proved to work better than those using a carbodiimide (EDC) and HOBt or HATU and DIPEA in anhydrous DMF without $\mathrm{LiCl}$ as coupling agents. The expected conjugate was obtained as a white solid (overall yield 22\%) after purification by reversedphase HPLC and lyophilisation (Figure S4), and was unambiguously characterized by high-resolution ESI MS and ${ }^{1} \mathrm{H}$ NMR spectroscopy. As shown in Figure 1, the obtained $\mathrm{m} / \mathrm{z}$ values display the expected isotopic mass distribution pattern of $\mathrm{Pt}$ and are consistent with the calculated value of the charged species $[\mathrm{M}+\mathrm{H}]^{+},[\mathrm{M}-\mathrm{Cl}]^{+}$and $[(\mathrm{M}-\mathrm{Cl})+\mathrm{H}]^{2+}$. In addition, the aromatic region of the ${ }^{1} \mathrm{H}$ NMR spectra shows diagnostic peaks from the Pt complex (dmba ligand) and the peptide moiety (amide $\mathrm{NH}$ protons and aromatic protons of $D$-Phe), confirming the covalent attachment of both moieties. The stability of the Pt$\mathrm{c}$ (RGDfK) conjugate (3) in $\mathrm{H}_{2} \mathrm{O}$ and in physiological-like conditions (PBS buffer, $\mathrm{pH}$ 7.4) was also investigated. As shown in Figure S5, more than $90 \%$ of conjugate 3 remained unaltered after incubation at $37^{\circ} \mathrm{C}$ for $24 \mathrm{~h}$ under the two conditions.

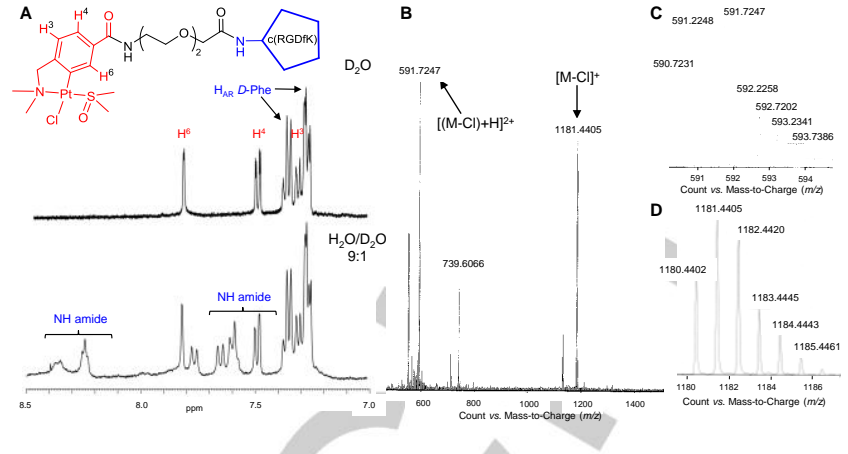

Figure 1. (A) Aromatic region of the ${ }^{1} \mathrm{H}$ NMR spectra of conjugate 3 in $\mathrm{D}_{2} \mathrm{O}$ and $\mathrm{H}_{2} \mathrm{O}-\mathrm{D}_{2} \mathrm{O}$ 9:1. (B) HR ESI mass spectrum of 3 and expanded region of the molecular peaks $[(\mathrm{M}-\mathrm{Cl})+\mathrm{H}]^{2+}(\mathrm{C})$ and $[\mathrm{M}-\mathrm{Cl}]^{+}(\mathrm{D})$, showing the isotopic distribution pattern of platinum.

\section{Selection of cell lines overexpressing $\alpha_{\mathrm{v}} \beta_{3}$ and $\alpha_{\mathrm{v}} \beta_{5}$ integrins}

Having at hand the Pt-c(RGDfK) conjugate (3), we first studied the expression levels of $\alpha_{v} \beta_{3}$ and $\alpha_{v} \beta_{5}$ integrins in a panel of cancer cell lines to choose the best model for investigating how the cytotoxic activity of the parent complex (2) is affected due to peptide conjugation. In good agreement with previous studies, ${ }^{[25}$ ${ }^{26]}$ we found that SK-MEL-28 cells expressed high levels of $\alpha_{v} \beta_{3}$ integrin whereas a very low expression of both integrins was found in CAPAN-1 cells (Figure 2). These results indicate that the melanoma cell line is a good model of cells overexpressing $\alpha_{v} \beta_{3}$ whereas the pancreatic cancer cells can be used as the negative control. In contrast, MDA-MB-231 cells exhibit similar expression levels of $\alpha v \beta_{5}$ than SK-MEL-28 but the negligible expression of $\alpha_{v} \beta_{3}$ makes breast cancer cells a suitable model of cells overexpressing $\alpha_{v} \beta_{5}$.

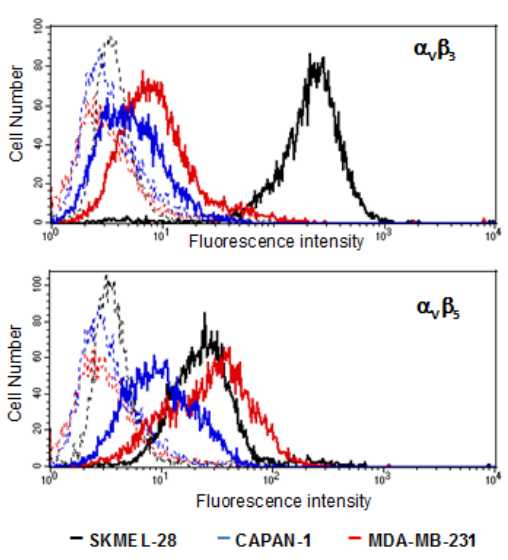

Figure 2. Expression of $\alpha_{v} \beta_{3}$ and $\alpha_{v} \beta_{5}$ integrins on SK-MEL-28, MDA-MB-231 and CAPAN-1 cell lines. Representative flow cytometry histograms obtained after the indirect immunofluorescence staining of the cells. Solid lines represent the fluorescence intensity of the cells after the incubation with monoclonal antibodies against $\alpha_{v} \beta_{3}$ and $\alpha_{v} \beta_{5}$ integrins followed by the incubation with the secondary antibody conjugated to Alexa-Fluor 488. Dotted lines indicate the background staining with the secondary antibody alone. 


\section{Cytotoxicity studies}

The anti-proliferative activities of Cilengitide, complex 2 and of the $\mathrm{Pt}-\mathrm{c}(\mathrm{RGDfK})$ bioconjugate (3) were determined in the selected cell lines using the MTT (3-(4,5-dimethylthiazol-2-yl)2,5-diphenyltetrazolium bromide) tetrazolium reduction assay, as well as that of cisplatin which was included for comparison purposes. First, it is worth noting that the cytotoxic activity of the parent Pt complex (2) was lower in all the cell lines tested (Table 1 and Figure 3) compared with A2780 cells, which were previously found highly sensitive to this compound $\left(\mathrm{IC}_{50}=0.98\right.$ $\mu \mathrm{M}) .{ }^{[24]}$ Second, the cytotoxicity of $\mathbf{2}$ was drastically reduced $\left(\mathrm{IC}_{50}>100 \mu \mathrm{M}\right)$ after conjugation to the peptide. This result was not completely unexpected taking into account the low cytotoxic activity of the parent Pt complex in $\alpha_{v} \beta_{3} / \alpha_{v} \beta_{5}+$ cells, and the fact that conjugation is usually accompanied by a reduction of the antitumor activity of the free metallodrug. ${ }^{[32-36]}$ Furthermore, it was found that Cilengitide was not cytotoxic in any of the cell lines tested.

Table 1. Sensitivity of SK-MEL-28, MDA-MB-231, CAPAN-1 and HUVEC cells to cisplatin, Cilengitide and compounds 2 and $\mathbf{3}$.

\begin{tabular}{lcccc}
\hline $\mathrm{IC}_{50}(\mu \mathrm{M})^{[\mathrm{a}]}$ & Compounds & & & \\
\hline Cell line & Cisplatin & Cilengitide & $\mathrm{Pt}, \mathbf{2}$ & $\mathrm{Pt}-\mathrm{C}(\mathrm{RGDfK}), 3$ \\
\hline SK-MEL-28 & $17.0 \pm 5.4$ & $>100$ & $38.2 \pm 8.6$ & $>100$ \\
MDA-MB-231 & 18.04 & $>100$ & $10.6 \pm 2.4$ & $>100$ \\
CAPAN-1 & $9.9 \pm 0.6$ & $>100$ & $31.4 \pm 7.8$ & $>100$ \\
HUVEC & $2.9 \pm 0.4$ & $>100$ & $4.61 \pm 0.5$ & $>100$ \\
\hline
\end{tabular}

[a] The concentration of the compounds that inhibits cells viability by $50 \%$ $\left(\mathrm{IC}_{50}\right)$ after $48 \mathrm{~h}$ was determined by the MTT assay. Each value represents the mean of three independent experiments \pm SD.
Very interestingly, we observed a marked effect of the Pt$c($ RGDfK) conjugate (3) on the morphology of $\alpha_{v} \beta_{3}$-overexpressing SK-MEL-28 cells and $\alpha_{v} \beta_{5}$-overexpressing MDA-MB-231 cells. Indeed, the exposure of the cells to the conjugate $\mathbf{3}$ or to Cilengitide induced morphological changes followed by cell detachment from the plate surface and a slight reduction of the number of adherent cells. In contrast, no disruption of the morphology of the $\alpha v \beta_{3} / \alpha_{v} \beta_{5}-$ CAPAN- 1 cells was observed at equimolar concentrations of the compounds (Figure 4). Thus, the similar behavior of 3 and Cilengitide indicates that the conjugate is able to retain part of the activity of the $\alpha v \beta_{3}$ antagonist peptide, which was previously found to cause detachment of HMEC-1 endothelial and glioma cells leading to the induction of apoptosis by direct activation of caspase-8. ${ }^{[37]}$ However, cell viability of SK-MEL-28, MDA-MB231 and CAPAN-1 was not affected after the treatment with either Cilengitide or the conjugate (3), which might be attributed to the distinct origin of the cells tested. In fact, inhibition of cell adhesion has been found to be dependent of the matrix used in glioma cells ${ }^{[38]}$ whereas the effect on endothelial and tumor cells still remains unclear. ${ }^{[37]}$ On the other hand, the disruption of the integrin-mediated cell adhesion by Cilengitide has been also linked to its anti-angiogenic properties, ${ }^{[38]}$ which prompted us to investigate the anti-angiogenic activity of the conjugate (see below). The Human Umbilical Vein Endothelial Cell (HUVEC) line was chosen for the experiments since it constitutively expresses integrins involved in angiogenesis $\left(\alpha_{v} \beta_{3}, \alpha_{v} \beta_{5}\right.$ and $\left.\alpha_{5} \beta_{1}\right) .{ }^{[39]}$ Prior to that experiments, the antiproliferative activity of Cilengitide, complex 2 and conjugate $\mathbf{3}$ in HUVEC cells was studied in order to subsequently work under sub-cytotoxic concentrations. As previously found for $\alpha_{v} \beta_{3}$ and $\alpha_{v} \beta_{5}-$ overexpressing cell lines (SK-MEL-28 and MDA-MB-231, respectively), both Cilengitide and the Pt-c(RGDfK) conjugate 3 were found non-toxic $\left(\mathrm{IC}_{50}>100 \mu \mathrm{M}\right.$; see Table 1).

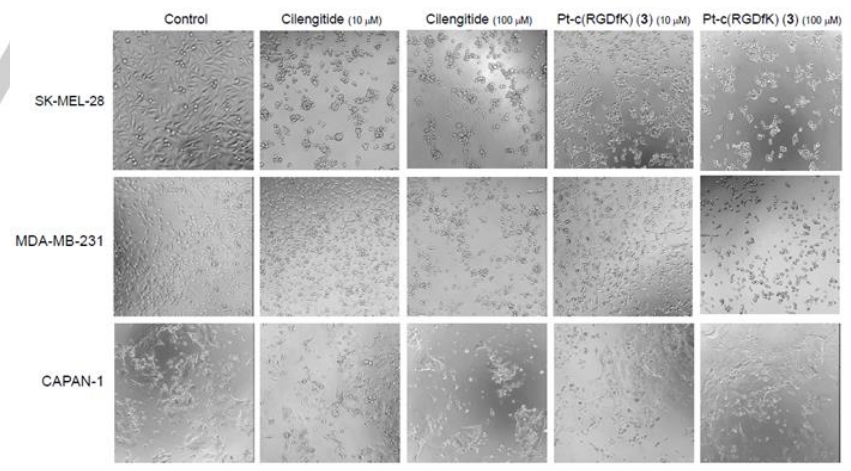

Figure 3. Viability determined by MTT assay of SK-MEL-28 (A), MDAMB-231 (B), CAPAN-1 (C) and HUVEC (D) cells after treatment with the compounds for $48 \mathrm{~h}$. Cilengitide $(\boldsymbol{\nabla})$, Pt (2) (๑), Pt-c(RGDfK) (3) (A) and cisplatin $(O)$. Results are the mean \pm SDs from three independent experiments.
Figure 4. Representative microscopy images of SK-MEL-28, MDA-MB-231 and CAPAN-1 cells showing changes in the cell morphology after $48 \mathrm{~h}$ exposure to medium alone (control), Cilengitide and Pt-c(RGDfK) conjugate (3).

\section{Angiogenesis inhibition studies}

B

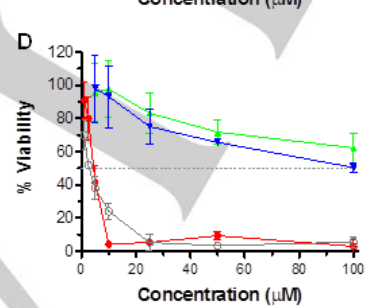

Considering that endothelial cell proliferation is essential in the multistep process of angiogenesis, in vitro vascular tube formation assay was measured $24 \mathrm{~h}$ after incubating HUVEC cells with conjugate 3 at 1,10 and $100 \mu \mathrm{M}$ concentrations. Cilengitide drug and complex 2 were used for comparative 
purposes and the negative control (untreated cells) was considered as $100 \%$ of capillary formation. The results of the two-dimensional Matrigel assay (Figure 5 and Figures S6-S7) were quantified as \% capillary formation by calculating the following parameters: number of master segments, number of meshes (network or polygonal structures), and number of master junctions. The formation of capillary-like structures was inhibited by complex 2 in a dose-dependent manner (Figures S6-S7), although it should be noted that at high concentrations its cytotoxicity is playing the central role $\left(\mathrm{IC}_{50} 4.61 \mu \mathrm{M}\right.$, see Table 1). In contrast, a slight inhibitory effect on HUVEC endothelial cells was observed for Cilengitide and the Pt$\mathrm{c}(\mathrm{RGDfK})$ conjugate (3) at all the tested concentrations. In both cases, the higher activity was found at $10 \mu \mathrm{M}$ with no further enhancement at $100 \mu \mathrm{M}$. Interestingly, the effect of $3(18.47 \% \pm$ $7.41 \% ; p>0.05)$ was higher with respect to Cilengitide $(0 \% ; p>$ $0.05)$ at the lower concentration $(1 \mu \mathrm{M}$, Figure 5$)$.
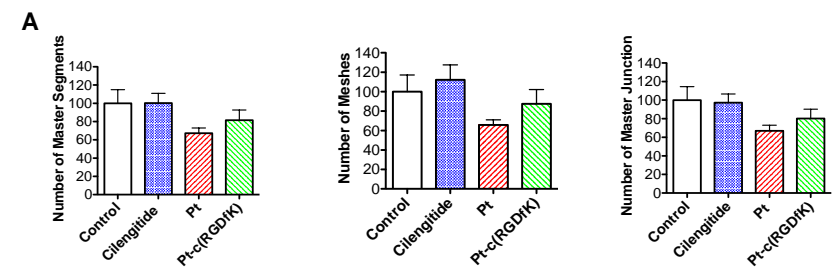

B

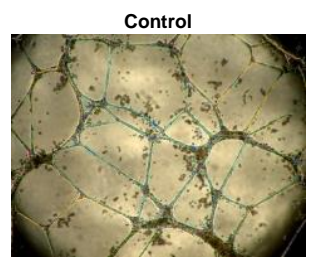

(2)
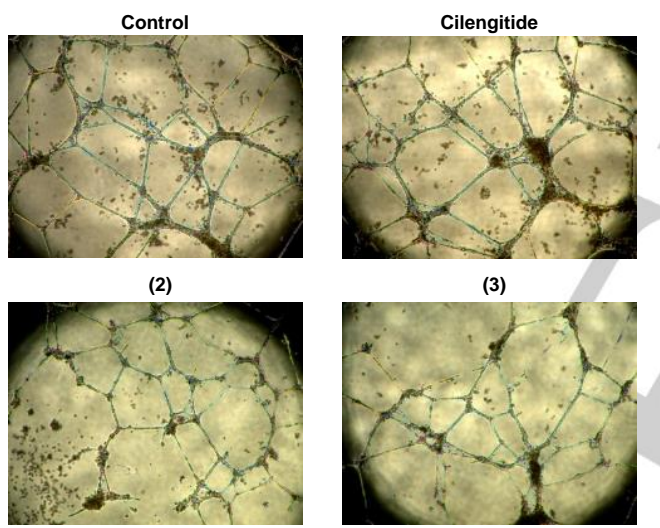

Figure 5. Effect of Cilengitide and compounds 2 and $3(1 \mu \mathrm{M}$ treatment, $24 \mathrm{~h})$ in the endothelial tube-like formation assay. (A) Quantification after the ImageJ process of number of master segments (left), number of meshes (center) and number of master junctions (right) of HUVEC cells. Values are expressed as mean \pm standard error of the mean. (B) Representative phase contrast photomicrographs of HUVEC cells plated on Matrigel in basal conditions or in the presence of Cilengitide or the compounds 2 or 3 at $1 \mu \mathrm{M}$ concentration.

However, it should be noted that the use of Cilengitide at low doses can stimulate angiogenesis, whereas a potent activity to block angiogenesis has been demonstrated in vivo. ${ }^{[40]}$ In addition, the lack of activity of Cilengitide in our in vitro model may be attributed to its inability to mimic crucial aspects of capillary morphogenesis in vivo. ${ }^{[41]}$ Overall, the results are in agreement with the fact that peptide conjugation alters the global mechanism of action of the free $\mathrm{Pt}$ (II) drug. In fact, peptide conjugation supposes, as previously stated, the loss of anticancer activity, whereas the anti-angiogenic properties seem to be closer to those of the $\alpha v \beta_{3}$ antagonist peptides. The overall results suggest that the anti-angiogenic properties of RGD- containing peptides can be modified through conjugation to metal complexes with high anti-angiogenic activity.

\section{Conclusions}

In summary, we have described the synthesis and characterization of a novel conjugate between a cyclometalated platinum(II) complex with dual antiangiogenic and antitumor activity and a cyclic RGD-containing peptide by combining SPPS and solution-phase methodologies. Peptide conjugation rendered a non-cytotoxic compound $\left(\mathrm{IC}_{50}>100 \mu \mathrm{M}\right)$ in all the tested tumor cell lines $\left(+/-\alpha_{v} \beta_{3}\right.$ and $\alpha_{v} \beta_{5}$ integrin receptors), which suggests that the mechanism of action of the parent $\mathrm{Pt}$ complex is modified. On the other hand, a similar angiogenesispattern activity to that of the reference Cilengitide drug at subcytotoxic concentrations was found in HUVEC cells for the Pt$c($ RGDfK) conjugate, which opens the way to exploring the development of novel potential angiogenesis inhibitors through conjugation of compounds with high anti-angiogenic activity such as metal complexes or small organic molecules ${ }^{[42]}$ to cyclic RGD-containing peptides or peptidomimetic analogues.

\section{Experimental Section}

General Methods. Common chemicals and solvents (HPLC-grade or reagent-grade quality) were purchased from commercial sources and used without further purification. Milli-Q water was directly obtained from a Milli-Q system equipped with a 5000 Da ultrafiltration cartridge. Peptide-grade DMF was from Scharlau. Fmoc-protected amino acids, resins, and coupling reagents for solid-phase synthesis were obtained from Novabiochem, Bachem, or Iris Biotech. Fmoc-L-Lys(Boc-AEEA)-OH was purchased from Iris. Solid-phase syntheses were performed manually in a polypropylene syringe fitted with a polyethylene disk. Metal complex Pt (2) ${ }^{[24]}$ and the $\mathrm{c}(\mathrm{RGDfK})$ peptide (5) bearing the linker ${ }^{[25-26]}$ were synthesized and characterized as previously reported. All the assayed compounds displayed a purity of $\geq 95 \%$, determined by HPLC analysis. Cilengitide was purchased from Bachem.

Solid-phase peptide syntheses were performed on a 2-chlorotritylchloride resin ( $f=0.52 \mathrm{mmol} / \mathrm{g}, 100-200$ mesh) using standard Fmoc/ ${ }^{\mathrm{B}} \mathrm{Bu}$ chemistry and the following protecting groups: Boc $\left(N^{\varepsilon}\right.$-tert butoxycarbonyl, Lys), Pbf ( $N^{G}-2,2,4,6,7$-pentamethyldihydrobenzofuran5-sulfonyl, Arg) and ${ }^{\mathrm{t}} \mathrm{Bu}$ (O-tert-butyl, Asp). Analytical reversed-phase HPLC analyses were carried out on a Jupiter Proteo $\mathrm{C}_{18}$ column $(250 \times$ $4.6 \mathrm{~mm}, 90 \AA 4 \mu \mathrm{m}$, flow rate: $1 \mathrm{~mL} / \mathrm{min}$ ) using linear gradients of $0.1 \%$ formic acid or $0.045 \%$ TFA in $\mathrm{H}_{2} \mathrm{O}$ (solvent $A$ ) and $0.1 \%$ formic acid or $0.036 \%$ TFA in ACN (solvent B). Large-scale purification was carried out on a Jupiter Proteo semipreparative column $(250 \times 10 \mathrm{~mm}, 10 \mu \mathrm{m}$, flow rate: $3 \mathrm{~mL} / \mathrm{min}$ ), using linear gradients of $0.1 \% \mathrm{HCOOH}$ in $\mathrm{H}_{2} \mathrm{O}$ (solvent A) and $0.1 \% \mathrm{HCOOH}$ in $\mathrm{ACN}$ (solvent $\mathrm{B}$ ). After several runs, pure fractions were combined and lyophilized. NMR spectra were recorded at $25^{\circ} \mathrm{C}$ on a Bruker $300 \mathrm{MHz}$ or $400 \mathrm{MHz}$ spectrometer using DMSO- $d_{6}$ or $\mathrm{D}_{2} \mathrm{O}$. The residual signal of the solvent was used as a reference for ${ }^{1} \mathrm{H}$ and ${ }^{13} \mathrm{C}$ spectra. Low-resolution ESI mass spectra (LR ESI MS) were recorded on a Micromass $Z Q$ instrument with single quadrupole detector coupled to an HPLC. High-resolution electrospray mass spectra (HR ESI MS) were obtained on an Agilent 1100 LC/MS-TOF instrument.

\section{Synthesis and characterization of the compounds}

4-(Dimethylamino)methyl)benzoic acid. A solution of 4(chloromethyl)benzoic acid $(1 \mathrm{~g}, 5.86 \mathrm{mmol})$ in dry THF $(15 \mathrm{~mL})$ was dropped to a stirred solution of $\mathrm{NHMe}_{2}(2.62 \mathrm{~mL}, 14.65 \mathrm{mmol})$ in dry THF 
(15 mL). The resulting solution was stirred overnight at RT under $\mathrm{N}_{2}$ atmosphere. The volume of the reaction was reduced under vacuo and the desired product precipitated as a white solid. The precipitate was collected by filtration, washed with cold $\mathrm{EtOH}$ and dried to give 4(dimethylamino)methyl)benzoic acid as a white powder $(570 \mathrm{mg}, 45 \%$ ). ${ }^{1} \mathrm{H}$ NMR $\left(300 \mathrm{MHz}, \mathrm{D}_{2} \mathrm{O}\right): \delta 7.73\left(\mathrm{dd}, 2 \mathrm{H}, J_{\mathrm{HH}}=6.3 \mathrm{~Hz}, J_{\mathrm{HH}}=1.8 \mathrm{~Hz}\right)$, $7.35\left(\mathrm{dd}, 2 \mathrm{H}, J_{\mathrm{HH}}=6.6 \mathrm{~Hz}, J_{\mathrm{HH}}=1.8 \mathrm{~Hz}\right), 4.18\left(\mathrm{~s}, 2 \mathrm{H}, \mathrm{CH}_{2} \mathrm{~N}\right), 2.70(\mathrm{~s}, 6 \mathrm{H}$ $\left.\mathrm{N}\left(\mathrm{CH}_{3}\right)_{2}\right) .{ }^{13} \mathrm{C}\left\{{ }^{1} \mathrm{H}\right\} \mathrm{NMR}\left(100 \mathrm{MHz}, \mathrm{D}_{2} \mathrm{O}\right): \delta 174.59(\mathrm{~s}, \mathrm{COOH}), 137.72(\mathrm{~s}$, Q), 131.73 (s, Q), 130.47 (s, CH), 129.32 (s, CH), 60.50 (s, NCH $), 42.02$ (s, $\left.\mathrm{N}\left(\mathrm{CH}_{3}\right)_{2}\right)$. HR MS $\left(\mathrm{ESI}+, \mathrm{H}_{2} \mathrm{O}\right): \mathrm{m} / z \quad 180.1025\left([\mathrm{M}+\mathrm{H}]^{+}\right.$, calcd. 180.1019).

Pt-COOH, 4. The method was adapted from the previous described by us. ${ }^{[24]}$ A suspension of cis-[ $\left.\mathrm{PtCl}_{2}(\mathrm{DMSO})_{2}\right](150 \mathrm{mg}, 0.36 \mathrm{mmol})$, 4(dimethylamino)methyl)benzoic acid $(64 \mathrm{mg}, 0.36 \mathrm{mmol})$ and $\mathrm{NaOAc}(58$ $\mathrm{mg}, 0.71 \mathrm{mmol})$ in absolute $\mathrm{EtOH}(20 \mathrm{~mL})$ was stirred under $\mathrm{N}_{2}$ at $65^{\circ} \mathrm{C}$ for $5 \mathrm{~h}$. The resulting hot solution was filtered under a plug of celite in order to remove the decomposition products. The pale yellow solution was then concentrated under vacuum, and a white solid precipitated. The solid was filtrated, washed several times with $\mathrm{H}_{2} \mathrm{O}$ to remove the excess of free ligand and vacuum-dried. White solid. Yield: $55 \%$. Anal. Calcd. for $4 \mathrm{C}_{12} \mathrm{H}_{18} \mathrm{CINO}_{3} \mathrm{PtS}$ : C, 29.60; $\mathrm{H}, 3.73 ; \mathrm{N}, 2.88$; S, 6.59. Found: C, 29.58; $\mathrm{H}, 3.75$; N, 2.83; S, 6.61. ${ }^{1} \mathrm{H}$ NMR (400 MHz, DMSO- $\left.d_{6}\right): \delta 12.48$ (brs, $1 \mathrm{H}$ $\mathrm{COOH}), 8.48\left(\mathrm{~d}, 1 \mathrm{H}, \mathrm{H}^{6}, J_{\mathrm{HH}}=1.6 \mathrm{~Hz}\right.$, Pt satellites are observed as shoulders), $7.61\left(\mathrm{dd}, 1 \mathrm{H}, \mathrm{H}^{4}, J_{\mathrm{HH}}=7.6 \mathrm{~Hz}, J_{\mathrm{HH}}=1.6 \mathrm{~Hz}\right), 7.16\left(\mathrm{~d}, 1 \mathrm{H}, \mathrm{H}^{3}\right.$, $\left.J_{\mathrm{HH}}=7.6 \mathrm{~Hz}\right), 4.08\left(\mathrm{~s}, 2 \mathrm{H}, \mathrm{CH}_{2} \mathrm{~N}\right.$, Pt satellites are observed as shoulders), $2.78\left(\mathrm{~s}, 6 \mathrm{H}, \mathrm{N}\left(\mathrm{CH}_{3}\right)_{2}\right), 2.54\left(\mathrm{~s}, 6 \mathrm{H}, \mathrm{SCH}_{3}\right) \cdot{ }^{13} \mathrm{C}\left\{{ }^{1} \mathrm{H}\right\} \mathrm{NMR}(100 \mathrm{MHz}$, DMSO- $\left.d_{6}\right): \delta 169.24(\mathrm{~s}, \mathrm{Q}), 153.68(\mathrm{~s}, \mathrm{Q}), 137.98(\mathrm{~s}, \mathrm{Q}), 136.16\left(\mathrm{~s}, \mathrm{CH}^{6}\right)$, $128.85(\mathrm{~s}, \mathrm{Q}), 126.87\left(\mathrm{~s}, \mathrm{CH}^{4}\right), 122.79\left(\mathrm{~s}, \mathrm{CH}^{3}\right), 76.63\left(\mathrm{~s}, \mathrm{CH}_{2} \mathrm{~N}, \mathrm{~J}_{\mathrm{CPt}}=\right.$ $55.8 \mathrm{~Hz}), 52.96\left(\mathrm{~s}, \mathrm{~N}\left(\mathrm{CH}_{3}\right)_{2}\right) .{ }^{195} \mathrm{Pt} \mathrm{NMR}(86.18 \mathrm{MHz}$, DMSO-d 6 ): $\delta$ 3635.54 (s). HR MS $\left(\mathrm{ESI}_{+}, \mathrm{DMSO} / \mathrm{H}_{2} \mathrm{O}\right): \mathrm{m} / z 451.0637$ ([M-Cl] ${ }^{+}$, calcd. 451.0656).

Pt-c(RGDfK) conjugate, 3. The Pt-COOH complex $4(8.9 \mathrm{mg}, 1.5 \mathrm{~mol}$ equiv.) was activated with HATU (4.9 $\mathrm{mg}, 1.05 \mathrm{~mol}$ equiv.) and DIPEA (2.1 $\mu \mathrm{L}, 1.0 \mathrm{~mol}$ equiv.) in anhydrous DMF $(0.8 \mathrm{M} \mathrm{LiCl}, 1 \mathrm{~mL})$. After stirring for $10 \mathrm{~min}$ at $\mathrm{RT}$, the reaction mixture was added to the peptide $(10.5 \mathrm{mg}, 12.2 \mu \mathrm{mol})$ previously dissolved in anhydrous DMF $(0.8 \mathrm{M} \mathrm{LiCl}$, $4 \mathrm{~mL}$ ) and DIPEA (2.1 $\mu \mathrm{L}, 1.0 \mathrm{~mol}$ equiv.). After stirring for $2 \mathrm{~h} 30 \mathrm{~min}$ at RT under argon atmosphere, the solvent was evaporated in vacuo and the conjugate was purified by semipreparative HPLC (gradient from 0 to $50 \% \mathrm{~B}$ in $40 \mathrm{~min}$, flow rate: $3 \mathrm{~mL} / \mathrm{min}, \mathrm{t}_{\mathrm{B}}=26.4 \mathrm{~min}$ ). Overall yield (synthesis + purification): $22 \%$. Characterization: $\mathrm{R}_{\mathrm{t}}=14.2 \mathrm{~min}$ (analytical gradient: 0 to $50 \%$ in $30 \mathrm{~min}$ ); HR MS $\left(\mathrm{ESI}_{+}, \mathrm{H}_{2} \mathrm{O}\right): \mathrm{m} / z 1181.4405$ (calcd. mass for $\mathrm{C}_{45} \mathrm{H}_{68} \mathrm{~N}_{11} \mathrm{O}_{12} \mathrm{PtS}$ [M-Cl] : 1181.4415), m/z 591.7247 (calcd. mass for $\left[\mathrm{C}_{45} \mathrm{H}_{69} \mathrm{~N}_{11} \mathrm{O}_{12} \mathrm{PtS}(\mathrm{M}-\mathrm{Cl})+\mathrm{H}\right]^{+}$: 591.7247$)$. Purity by HPLC: $97.7 \%$ by area.

Cell lines and culture condition. The SK-MEL-28 human melanoma, CAPAN-1 human pancreas adenocarcinoma and MBA-MD-231 human breast adenocarcinoma cell lines were obtained from the American Tissue Culture Collection (ATCC, Rockville, MD, USA). Cells were maintained in Dulbecco's Modified Eagle Medium (DMEM) supplemented with $10 \%$ FBS (Gibco-BRL, Grand Island, NY, USA) and $100 \mathrm{U} \mathrm{mL}^{-1}$ penicillin-streptomycin (Gibco-BRL). Human Umbilical Vein Endothelia Cells (HUVECs, Lonza) were cultured on 1\% Type B gelatin from bovine skin (Sigma) in Endothelial cell Basal Medium EBM (Lonza), supplemented with hEGF, hydrocortisone, brain bovine extract and gentamicine (EGM, Lonza), and 10\% FCS (PAA). Cells were cultured between passages 7 and 9 and all experiments were carried out at 80 $85 \%$ of confluence, with the same batch of cells. All cells were cultured at $37{ }^{\circ} \mathrm{C}$ in a humidified $5 \% \mathrm{CO}_{2}$-atmosphere, and were consistently free of mycoplasma as evaluated by EZ-PCR mycoplasma test kit (Biological Industries). Cell growth and morphology were assessed using an inverted microscope.

Integrin expression analysis. The expression of $\alpha_{v} \beta_{3}$ and $\alpha v \beta_{5}$ integrins on the cell surface was analyzed by double immuno- fluorescence. The cells were incubated for $30 \mathrm{~min}$ at $4{ }^{\circ} \mathrm{C}$ with monoclonal antibodies against human $\alpha_{v} \beta_{3}$ (clone LM609) (Millipore, Temecula, CA) and $\alpha_{v} \beta_{5}$ integrin (sc-81632) (Santa Cruz Biotechnology, Santa Cruz, CA, USA) or medium alone as negative control. After washing with phosphate-buffered saline (PBS) (Gibco-BRL), cells were incubated for additional $30 \mathrm{~min}$ at $4 \stackrel{\circ}{\circ} \mathrm{C}$ with the Alexa-Fluor 488 conjugated goat anti-mouse IgG antibody (Invitrogen, Carlsbad, CA, USA). Next, the cell fluorescence was analyzed using a FACSCalibur flow cytometer (Becton Dickinson Immunocytometry Systems, San Jose, CA, USA) equipped with CellQuestTM software (Becton Dickinson). 10000 cells were analyzed in each experiment. Fluorescence intensity was represented on a four orders of magnitude log scale (1-10000).

Cell viability studies. The cytotoxicity of the compounds in SK-MEL-28, CAPAN-1, MDA-MB-231 and HUVEC cells was determined by the MTT (3-(4,5-dimethylthiazol-2-yl)-2,5-diphenyltetrazolium bromide) tetrazolium reduction assay. Cilengitide and Pt-RGD conjugate (3) were dissolved in Milli-Q water to obtain $1 \mathrm{mM}$ stock solutions. Cisplatin (Sigma-Aldrich, St. Louis, MO) and the platinum complex 2 were dissolved in DMSO to provide a $10 \mathrm{mM}$ solution, which was then diluted in Milli-Q to obtain a 1 $\mathrm{mM}$ stock solution. Appropriate aliquots of these solutions were diluted in the cell culture medium to obtain the final working solutions. Aliquots of 5000 CAPAN-1, 4000 SK-MEL-28, 5000 MDA-MB-231 and 2500 HUVEC cells were seeded on 96 -well plates $24 \mathrm{~h}$ prior to the treatments. Then, cells were treated for $48 \mathrm{~h}$ with the corresponding compound at concentrations ranging from 0 to $100 \mu \mathrm{M}$ After removal of the treatment, cells were washed with PBS. Before the MTT colorimetric assay, representative images (10X) of the cells exposed to the each treatment were obtained with a CKX41 inverted microscope (Olimpus). Then, cells were incubated for $2 \mathrm{~h}$ in the dark with fresh culture medium $(100 \mathrm{~mL})$ containing MTT $(10 \mu \mathrm{L})$. The medium was discarded and DMSO $(100 \mu \mathrm{L})$ was added to each well to dissolve the purple formazan crystals. Plates were agitated at RT for $2 \mathrm{~min}$ and the absorbance of each well was determined with an absorbance microplate reader (ELx800, BioTek Winooski, USA) at a wavelength of $570 \mathrm{~nm}$. Three replicates for each compound were used, and all treatments were tested at least in three independent experiments. For each treatment, the cell viability was determined as a percentage of the control untreated cells, by dividing the mean absorbance of each treatment by the mean absorbance of the untreated cells. The concentration that reduces by $50 \%$ the cell viability $\left(\mathrm{IC}_{50}\right)$ was established for each compound using a four-parameter curve fit (Gen5 Data Analysis Software, BioTeck).

Tube-like formation assay. To address the role played by the conjugation of the Pt complex to Cilengitide in the angiogenesis process, tube-like formation assay was used. Separated experiments were performed using Matrigel Basement Matrix Growth Factor Reduced (Corning 356231) as a substrate for HUVECs. Cells $\left(2 \times 10^{4}\right.$ in complete medium) were seeded onto 96 -well culture plate. Different concentrations of Pt, Pt-c(RGDfK) and Cilengitide $(1,10$ or $100 \mu \mathrm{M})$ were added to the wells and were incubated at $37{ }^{\circ} \mathrm{C}$ in a humidified $5 \% \mathrm{CO}_{2}$-atmosphere for $24 \mathrm{~h}$. Then, images of each well were acquired at a magnification of x10 and were analyzed using the Angiogenesis Analyzer for Image $J$ from Gilles Capentier. Data analysis was performed by normalizing the results with the negative control (untreated cells) that was considered as $100 \%$ of capillary formation.

Statistical analysis. Mean values, expressed as mean \pm standard error of the mean (SEM), were compared using the two-tailed non-parametric Mann-Whitney U-test (GraphPad Prism software, version 5.04 for Windows) and statistically significant value was taken as $p<0.05$.

\section{Acknowledgements}

This work was supported by the Spanish Ministry of Economy and Competitiveness and FEDER funds (Projects CTQ2014- 
52658-R, CTQ2015-64319-R and CTQ2017-84779-R). COST CM1105 and the MetDrugs network (CTQ2015-70371-REDT) are acknowledged for providing opportunities for discussion. A. Z. and A. G. thanks Fundacion Séneca-CARM (Exp. 19020/FPI/13) and the University of Barcelona, respectively, for a grant. A.M. thanks University of Girona for a grant (MPCUdG2016/076).

Keywords: RGD peptide $\cdot$ Cilengitide $\cdot$ cyclometalated Pt complexes $\bullet \mathrm{Pt}-\mathrm{RGD}$ conjugate $\cdot$ angiogenesis inhibitors

\section{References:}

[1] J. Folkman, Nat. Med. 1995, 1, 27-31.

[2] P. Carmeliet, R. K. Jain, Nature 2000, 407, 249-257.

[3] J. Welti, S. Loges, S. Dimmeler, P. Carmeliet, J. Clin. Invest. 2013, 123, 3190-3200.

[4] Z. Lin, Q. Zhang, W. Luo, Eur. J. Pharmacol. 2016, 793, 76-81.

[5] A. Close, Future Med. Chem. 2016, 8, 443-462.

[6] C. Mas-Moruno, F. Rechenmacher, H. Kessler, Anti-Cancer Agents Med. Chem. 2010, 10, 753-768.

[7] C. Mas-Moruno, R. Fraioli, F. Rechenmacher, S. Neubauer, T. G. Kapp, H. Kessler, Angew. Chem. Int. Ed. 2016, 55, 7048-7067.

[8] T. G. Kapp, F. Rechenmacher, S. Neubauer, O. V. Maltsev, E. A. Cavalcanti-Adam, R. Zarka, U. Reuning, J. Notni, H.-J. Wester, C. MasMoruno, J. Spatz, B. Geiger, H. Kessler, Sci. Rep. 2017, 7:39805.

[9] J B Vermorken, J Guigay, R Mesia, J M Trigo, U Keilholz, A Kerber, U Bethe, M Picard, T H Brummendorf, Brit. J. Cancer 2011, 104, 16911696

[10] J. Vansteenkiste, F. Barlesi, C. F. Waller, J. Bennouna, C. Gridelli, E. Goekkurt, D. Verhoeven, A. Szczesna, M. Feurer, J. Milanowski, P. Germonpre, H. Lena, D. Atanackovic, M. Krzakowski, C. Hicking, J. Straub,M. Picard, W. Schuette, K. O'Byrne K, Ann. Oncol. 2015; 26, 1734-1740.

[11] D. J. Craik, D. P. Fairlie, S. Liras, D. Price, Chem. Biol. Drug Des. 2013 81, 136-147.

[12] M. Góngora-Benítez, J. Tulla-Puche, F. Albericio, Chem. Rev. 2014, 114, 901-926.

[13] J. S. Desgrosellier, D. A. Cheresh, Nat. Rev. Cancer 2010, 10, 9-22.

[14] F. Danhier, A. Le Breton, V. Préat, Mol. Pharmaceutics 2012, 9, 2961 2973.

[15] D. Arosio, C. Casagrande, Adv. Drug Delivery Rev. 2016, 97, 111-143.

[16] S. Katsamakas, T. Chatzisideri, S. Thysiadis, V. Sarli, Future Med. Chem. 2017, 9, 579-604

[17] P. Nowak-Sliwinska, J. R. van Beijnum, A. Casini, A. Nazarov, G. Wagnières, H. van den Bergh, P. J. Dyson, A. W. Griffioen, J. Med Chem. 2011, 54, 3895-3902.

[18] L.-J. Liu, S. Lin, D. S.-H. Chan, C. T. Vong, P. M. Hoi, C.-Y. Wong, D.-L. Ma, C.-H. Leung, J. Inorg. Biochem. 2014, 140, 23-28.

[19] A. Wilbuer, D. H. Vlecken, D. J. Schmitz, K. Kräling, K. Harms, C. P. Bagowski, E. Meggers, Angew. Chem. Int. Ed. 2010, 49, 3839-3842.

[20] A. Kastl, A. Wilbuer, A. L. Merkel, L. Feng, P. Di Fazio, M. Ocker, E. Meggers, Chem. Commun. 2012, 48, 1863-1865.

[21] J.-J. Zhang, R. W.-Y. Sun, C.-M. Che, Chem. Commun. 2012, 48, 3388-3390.

[22] J. Yellol, S. A. Perez, A. Buceta, G. Yellol, A. Donaire, P. Szumlas, P. J. Bednarski, G. Makhloufi, C. Janiak, A. Espinosa, J. Ruiz, J. Med. Chem. 2015, 58, 7310-7327.

[23] S. A. Perez, C. de Haro, C. Vicente, A. Donaire, A. Zamora, J. Zajac, H. Kostrhunova, V. Brabec, D. Bautista, J. Ruiz, ACS Chem. Biol. 2017 12, 1524-1537.

[24] A. Zamora, S. A. Pérez; V. Rodríguez; C. Janiak; G. S. Yellol, J. Ruiz, J. Med. Chem. 2015, 58, 1320-1336.

[25] A. Massaguer, A. González-Cantó, E. Escribano, S. Barrabés, G. Artigas, V. Moreno, V. Marchán, Dalton Trans. 2015, 44, 202-212.
[26] A. Gandioso, E. Shaili, A. Massaguer, G. Artigas, A. González-Canto, J. A. Woods, P. J. Sadler, V. Marchán, Chem. Commun. 2015, 51, 91699172

[27] F. Barragán, V. Moreno, V. Marchán, Chem. Commun. 2009, 4705 4707.

[28] E. Shaili, M. Fernández-Gimenez, S. Rodriguez-Astor, A. Gandioso, L. Sandin, C. García-Velez, A. Massaguer, G. J. Clarkson, J. A. Woods, P. J. Sadler, V. Marchán, Chem. Eur. J. 2015, 21, 18474-18486.

[29] T. Chatzisideri, S. Thysiadis, S. Katsamakas, P. Dalezis, I. Sigala, T. Lazarides, E. Nikolakaki, D. Trafalis, O. A. Gederaas, M. Lindgren, V. Sarli, Eur. J. Med. Chem. 2017, 141, 221-231.

[30] M. A. Dechantsreiter, E. Planker, B. Mathä, E. Lohof, G. Hölzemann, A. Jonczyk, S. L. Goodman, H. Kessler, J. Med. Chem. 1999, 42, 3033 3040.

[31] R. Haubner, R. Gratias, B. Diefenbach, S. L. Goodman, A. Jonczyk, H. Kessler, J. Am. Chem. Soc. 1996, 118, 7461-7472.

[32] M. Soler, L. Feliu, M. Planas, X. Ribas, M. Costas, Dalton Trans. 2016, 45, 12970-12982.

[33] F. Barragán, D. Carrion-Salip, I. Gómez-Pinto, A. González-Cantó, P. J. Sadler, R. de Llorens, V. Moreno, C. González, A. Massaguer, V. Marchán, Bioconjugate Chem. 2012, 23, 1838-1855.

[34] E. M. Hahn, N. Estrada-Ortiz, Jiaying Han, V. F. C. Ferreira, Tobias G Kapp, J. D. G. Correia, Angela Casini, F. E. Kühn, Eur. J. Inorg. Chem. 2017, 1667-1672.

[35] M. A. Medrano, M. Morais, V. F. C. Ferreira, J. D. G. Correia, A. Paulo I. Santos, C. Navarro-Ranninger, A. Alvarez Valdes, A. Casini, F Mendes, A. G. Quiroga, Eur. J. Inorg. Chem. 2017, 1835-1840.

[36] A. C. Conibear, S. Hager, J. Mayr, M. H. M. Klose, B. K. Keppler, C. R Kowol, P. Heffeter, C. F. W. Becker, Bioconjugate Chem. 2017, 28 2429-2439.

[37] L. Oliveira-Ferrer, J. Hauschild, W. Fiedler, C. Bokemeyer, J. Nippgen I. Celik, G. Schuch, J. Exp. Clin. Cancer Res. 2008, 27:86

[38] T. Taga, A. Suzuki, I. Gonzalez-Gomez, F. H. Gilles, M. Stins, H. Shimada, L. Barsky, K. I. Weinberg, W. E. Laug, Int. J. Cancer 2002, 98, 690-697

[39] S. Aidoudi, K. Bujakowska, N. Kieffer, A. Bikfalvi, PLoS One, 2008, 3, e2657.

[40] P. C. Brooks, A. M. P. Montgomery, M. Rosenfeld, R. A. Reisfeld, T. Hu G. Klier, D. A. Cheresh, Cell 1994, 79, 1157-1164

[41] R. E. Nisato, J.-C. Tille, A. Jonczyk, S. L. Goodman, M. S. Pepper, Angiogenesis 2003, 6, 105-119.

[42] A. Sartori, E. Portioli, . Battistini, L. Calorini, A. Pupi, F. Vacondio, D. Arosio, F. Bianchini, F. Zanardi, J. Med. Chem. 2017, 60, 248-262. 


\section{Entry for the Table of Contents}

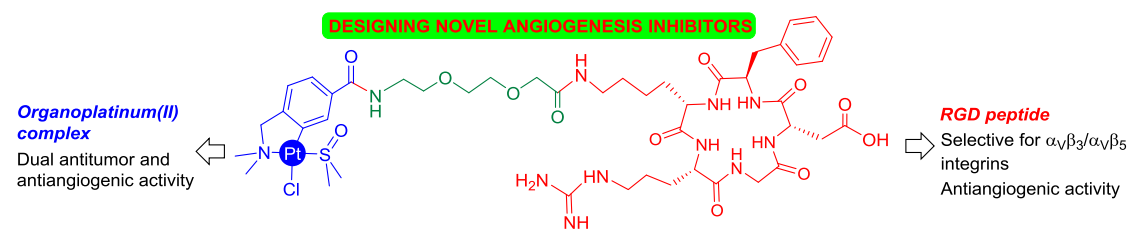

Conjugates of cyclometalated platinum(II) complexes and RGD peptides as potential angiogenesis inhibitors. 